\title{
The Renaissance in Toronto: Early Modern Italian Books in the Collections of the Thomas Fisher Rare Book Library ${ }^{1}$
}

\author{
ANTONIO RICCI \\ York University
}

The Thomas Fisher Rare Book Library at the University of Toronto has significant holdings of books printed in Italy during the Renaissance. These volumes cover a wide variety of disciplines and represent a major resource for scholars of literature, philosophy, science, and print culture. The article explains how the Renaissance material came to Toronto by tracing the historical formation of the rare books and special collections of the University Library. It then analyzes the main areas of strength of the Fisher's early modern holdings, offering representative examples of the most important editions and of the outstanding bibliographic treasures. Finally, it briefly considers the contribution made by the Fisher Library to Renaissance studies in Canada in the last fifty years.

La bibliothèque Thomas Fisher de livres rares de l'Université de Toronto possède une collection significative de livres imprimés en Italie à la Renaissance. Ces livres relèvent d'une variété de disciplines et constituent une importante ressource pour la recherche en littérature, en philosophie, en science, et en histoire de l'imprimerie. Cet article décrit comment ces livres de la Renaissance se retrouvent à Toronto, en retraçant l'histoire de la collection de livres rares et des collections spéciales de l'Université de Toronto. On y analyse ensuite les domaines majeurs de la collection Fisher de livres de la Renaissance, par le biais d'exemples des plus importantes éditions et des trésors bibliographiques inestimables. Enfin, on y décrit la contribution de la bibliothèque Fisher aux études canadiennes de la Renaissance des cinquante dernières années.

$\mathrm{T}$ he year 1964 witnessed three significant events in the history of Renaissance studies in Toronto and in Canada. Victoria College announced the establishment of the Centre for Reformation and Renaissance Studies (CRRS), a project spearheaded by F. David Hoeniger of its English Department. In October, Natalie Zemon Davis and James K. McConica, both connected to the University

1. I would like to thank Pearce J. Carefoote, David Fernández, and Anne Dondertman of the Fisher Library; Robin Healey and Miguel Torrens, respectively the past and current selectors for Italian studies in the Collection Development Department of the University of Toronto Libraries; my fellow book historian Scott Schofield; and Amyrose McCue Gill. Their assistance was indispensable in attempting safe navigation and in making reliable soundings of a collection as large, deep, and widely scattered as the Italian holdings of the Fisher.

Renaissance and Reformation / Renaissance et Réforme 37.3, Summer / été 2014 
of Toronto, founded the Toronto Renaissance and Reformation Bulletin, a publication that eventually became this journal. ${ }^{2}$ And the Toronto Renaissance and Reformation Colloquium (TRRC) started meeting in the fall. The Colloquium too was the initiative of Davis and McConica, who intended to foster dialogue and cooperation among the scholars working in the early modern period at the University of Toronto, York University, and other institutions in southern Ontario, a cohort growing fast in the wake of the expansion of the provincial university system, but dispersed along traditional disciplinary divides.

That year also represents another anniversary, albeit a symbolic one. It marks the halfway point between the founding in 1955 of the Department of Rare Books and Special Collections of the University of Toronto Library, and the opening in 1973 of the building designed to house it, the Thomas Fisher Rare Book Library. ${ }^{3}$ The two dates define a golden age. It was during this period that the institution's modest historical holdings of rare books were transformed into the premier collection of its kind in Canada and one of the best in North America, the heart of a general collection which in those years became itself one of the leading research libraries in the world.

The Fisher owns more than seven hundred thousand volumes and considerable holdings of manuscripts covering a vast array of subject areas. It is particularly strong in Canadiana, British and European literature, the history of science and medicine, philosophy, book history, Hebraica and Judaica, and theology. The library also holds a large and important collection of rare books printed in Italy during the Renaissance. ${ }^{4}$ These books are distributed in several named collections as well as in the library's general holdings, and they range across a wide variety of disciplines, with significant concentrations in literature, philosophy, book history and print culture, and science. The Fisher's Italian Renaissance collection is a major research resource which has supported Canadian and international scholars of early modern Italy and Europe for the last fifty years. It is an integral part of the history of Renaissance studies in Canada and it deserves to be celebrated in its own right.

2. On the history of the journal and the historical context of its founding, see Konrad Eisenbichler's contribution in this issue, which he generously made available to me prior to publication.

3. Further references to the Department of Rare Books and Special Collections will be given in the text as RBSC.

4. By books printed in the Renaissance, I mean titles that appeared between the introduction of printing and 1600 . 
Since the make-up of the Italian holdings is tied to the larger history of the University Library-the character of every library reflects its historical formation-I will first sketch out a short history of the Fisher outlining the various avenues by which the Renaissance rare books arrived in Toronto. I will then present a survey of the collections, focusing on the principal areas of strength and offering examples of the more significant editions and of the outstanding bibliographic treasures.

The modern library of the University of Toronto was born out of the great Valentine's Day fire of 1890, a conflagration that all but destroyed the original book collection. When a new building opened in 1892, an international campaign for the restoration of the library had brought in more than forty thousand volumes. ${ }^{5}$ Among them were books donated by the government of Italy as well as a beautiful edition of Piranesi's Opere Varie presented by the Free Libraries Committee of the City of Birmingham in $1890 .{ }^{6}$ After this first stage of reconstruction, the historical development of the Renaissance collections was influenced by the scholarly interests of the faculty in Italian Studies, a discipline that represents an unbroken tradition at the university for 160 years. The subject had been introduced to the curriculum in 1853 with the appointment as professor of Modern Languages at University College of James Forneri, a Piedmontese exile, carbonaro, Protestant convert, and indefatigable instructor. ${ }^{7}$ He was beloved by his students and respected by his colleagues, but in 1866, at the age of 77, he was demoted to lecturer without any official explanation. Maddalena Kuitunen and Julius A. Molinaro imply that the reservations of members of the university administration regarding foreigners played a role, citing a letter written in 1856 by the then vice chancellor, John Langton, in which he describes Forneri in

5. On the fire and its aftermath, see The Benefactors of the University of Toronto, after the Great Fire of 14th February, 1890 (Toronto: Williamson Book Co., 1892); Robin Healey, From Aquinas to Atwood: Celebrating Gifts in Italian Studies to the University of Toronto Library, 1890-2003 (Toronto: University of Toronto Library, 2003), 101-03; Maddalena Kuitunen and Julius A. Molinaro, A History of Italian Studies at the University of Toronto, 1840-1990 / Lo studio dell'italiano all'Università di Toronto (Toronto: Department of Italian Studies, University of Toronto, 1991), 18, 86.

6. Giovanni Battista Piranesi, Opere varie di architettura, prospettive, grotteschi, antichità, sul gusto degli antichi Romani (Rome: Si vendono presso l'Autore, 1750). See Healey, From Aquinas to Atwood, 103-04.

7. On the early history of Italian at Toronto and the role of Forneri (1789-1869), see Kuitunen and Molinaro, 6-13. His teaching load consisted of at least twenty-four lectures during the week and another five to eighteen hours devoted to other teaching duties. 
rather patronizing terms. ${ }^{8}$ In any case, Italian was kept in the curriculum, the Department of Italian and Spanish was established in 1887, and the program grew. The first record of a purchase of Italian Renaissance books dates to 1897, when the head of the department was William Henry Fraser:

The 16th-century Italian verse collection in the University of Toronto Library was begun at the end of the nineteenth century. The earliest acquisition dates back to September 1897 and was made through B. Seeber, a bookdealer in Florence, successor to Loescher and Seeber, 'by appointment to Her Majesty, the Queen of Italy.' Other additions followed in $1901 .^{9}$

This beginning was important, but of modest scope. So was the University Library's collection at the time, but it was growing apace under the direction of Hugh Hornby Langton, chief librarian from 1892 to $1923 .{ }^{10}$ The next milestone in the history of the institution's holdings of Italian rare books was a biblioagoristic voyage undertaken by Langton himself. Approaching retirement, he spent 1922 in Europe armed with "a fund especially set aside for the purchase of Italian books" and abetted by the expert advice of Milton A. Buchanan and James E. Shaw, professors of Italian. His acquisitions made considerable additions to the verse collection and in effect established the collection of Renaissance plays, a

8. Kuitunen and Molinaro, 11. Langton bemoaned the fact that French and German history were not taught by the History Department but were left to the programs in "those languages, which are under the care of a very worthy pudding-headed old Italian to whom they have been assigned upon the principle, which appears to be accepted elsewhere as well as in Canada, that foreign languages are safe in the hands of a foreigner. The foreign language department is also most contemptible which must I am afraid be laid at the door of poor Dr. Forneri." Langton's comments were made in the context of his criticism of the administration's poor general management of the university and its curriculum, the facile application of the "principle" of hiring foreigners simply because they were foreigners being an example. See "A Letter About University Affairs, Toronto, Nov. 12, 1856," in John Langton, Early Days in Upper Canada: Letters of John Langton from the Backwoods of Upper Canada and the Audit Office of the Province of Canada, ed. W. A. Langton (Toronto: Macmillan, 1926), 275-97, 290.

9. Julius A. Molinaro, A Bibliography of Sixteenth-Century Italian Verse Collections in the University of Toronto Library (Toronto: University of Toronto Press, 1969), xi.

10. See Robert H. Blackburn, "Langton, Hugh Hornby," in The Canadian Encyclopedia, 4 vols. (Edmonton: Hurtig Publishers, 1988), 2:1174. Blackburn was university librarian in 1954-81. 
major part of which was in place by $1924 .{ }^{11}$ Hugh was the son of John Langton. His contribution to the Italian collections redeemed, in a way, his father's rather unfair judgment of the university's first professor of Italian.

Langton's reliance on Buchanan and Shaw illustrates a constant in the last century: members of the faculty guided the purchase of Italian material. Professors also built up personal collections of a parallel nature, and in due course several of these came to complement the library's own as they retired and donated or bequeathed their books. Milton Buchanan is the best example of this tradition. A specialist in the Spanish Golden Age, he was a professor of Italian and Spanish from 1910 and department chair from 1917 until his retirement in $1946 .{ }^{12}$ During the three decades at the head of his program, his frequent, enthusiastic, and even tenacious recommendations shaped the library's acquisitions of Spanish and Italian books, both for the general collection and for the special collections. Buchanan was himself an avid bibliophile, and he built up a large private library of Italian, Spanish, and Portuguese books and periodicals well known for its rarities. He donated it to the university after he retired, and the gift went to form the basis of the Buchanan Collection. His last act of dedication to the institution keeps his influence alive today. In his will he arranged that after the death of his wife-which occurred in 1965, thirteen years after his own-his estate should pass to the university, and that its income should be used towards fellowships for undergraduate and graduate students as well as towards the purchase of books. Since then, proceeds from the Buchanan Fund have contributed total or partial funding for the acquisition of rare and special items in Italian, Spanish, and Portuguese. Thus, material continues to flow into the Fisher's Buchanan Collection, ${ }^{13}$ an ever-growing concentration of Italian Renaissance and Spanish literature.

When Buchanan died in 1952, the University Library was about to enter the second phase in its history, one determined by larger developments. A

11. Molinaro, xi. See also Beatrice Corrigan, Catalogue of Italian Plays, 1500-1700, in the Library of the University of Toronto (Toronto: University of Toronto Press, 1961), vii.

12. On Buchanan, see Jack H. Parker, “Milton Alexander Buchanan (1878-1952), Hispanic Review 20.4 (1952): 324-32; Parker, “A Great Hispanist: Milton A. Buchanan,” Bulletin of Spanish Studies 24.95 (1947): 182-84; Kuitunen and Molinaro, 41, 130. David Fernández provided valuable information on Buchanan and the special collection that bears his name.

13. I have drawn information from donor files in the Fisher Library archives, brought to my attention and made available by Pearce Carefoote. 
post-war economic and demographic boom of unprecedented proportions brought about a kind of national rebirth. Traditionally seen as a nation of "hewers of wood and drawers of water," in one generation Canada completed its transformation into an economically advanced, socially progressive, and multicultural country. Emblematic of the character of the times was the city of Toronto, which began to evolve from a continental transportation hub concerned with the sober and discreet cultivation of industrial and financial interests to a major urban centre with cultural aspirations. Among the consequences of the epochal changes was the massive expansion in the 1960s of the public university system in the province of Ontario, overseen by the Progressive Conservative government of Premier John Parmenter Robarts. Claude Bissell, the dynamic president of the University of Toronto at the time, embraced the spirit of the era and pursued a great vision for his institution: to make it into the leading research university in Canada. ${ }^{14} \mathrm{~A}$ sign of the confidence of the place was the presence on campus and the newfound international renown of professors Northrop Frye and Marshall McLuhan. McLuhan's Gutenberg Galaxy appeared in 1962, putting the "print revolution" at the forefront of academic inquiry and popular curiosity, and establishing media studies as a field. ${ }^{15}$ The university underwent a great expansion, adding buildings and campuses, but Bissell's real objective was the excellence of the academic programs. The reorganization and enlargement of the School of Graduate Studies was a central element of his plans, and in support of the school's programs, as well as undergraduate studies in general, he wanted a great research library. The development of the general collections also heralded the next phase for the library's holdings in rare books, a new beginning marked by an official milestone. In 1955, when Bissell was a vice president, Robert H. Blackburn, the chief librarian, founded the Department of Rare Books and Special Collections (RBSC) and chose Marion E. Brown to head it. She began by bringing together the existing rare materials, most of which were in the stacks of the main collection, and in 1957 she opened the Rare Book Room in what is now the Gerstein Information Centre, which made it possible to reassemble the Buchanan and other collections and to provide

14. Bissell was president from 1958 to 1971. See Robert Fulford's obituary: National Post, 5 September 2000, http://www.robertfulford.com/ClaudeBissell.html.

15. Marshall McLuhan, The Gutenberg Galaxy: The Making of Typographic Man (Toronto: University of Toronto Press, 1962). 
study space for researchers. ${ }^{16}$ These first initiatives, necessary and momentous as they were at the time, were soon overshadowed by the arrival of public funding in amounts that radically remade RBSC and the University Library in general. It is almost impossible now, after a long period of crisis for libraries, to imagine those heady times, when budgetary constraints were almost inconceivable. If it was possible for a nation achieving its centenary to change its flag, elect an intellectual prime minister, and choose a new national anthem, then it seemed only natural that every acquisition was possible for the library of the best university of the country. Geoffrey L. Stagg, the contemporary chair of Italian and Hispanic Studies, in later years recalled wistfully "the days of euphoria and abundance, when funds seemed unlimited; when the Library for a time was spending more on acquisitions than any other University Library on the continent (and perhaps in the world)." ${ }^{17}$

Government support allowed RBSC to flourish in the 1950s and in the 1960s. It is also true that during this period the rare book collections continued to benefit from private gifts and bequests, and that scholars still guided the acquisitions decisions of the rare book librarians. The tradition established by Buchanan was carried on by another professor in Italian Studies, Beatrice M. Corrigan, who actively advised the library in the 1960s and 1970s. Corrigan was a specialist in the Renaissance, especially its drama, and she held the first $\mathrm{PhD}$ in Italian awarded by the university. She also donated books from her own library. ${ }^{18}$ A number of the collections that came into the library at this time contained Italian Renaissance books. We have already seen the Buchanan bequest. Professor Gilbert Bagnani of the Department of Classics, an archeologist and classical scholar, donated his Petronius collection in 1960. The verse collection

16. For a history of the department, see the "Introduction" in Richard Landon, Bibliophilia Scholastica Floreat: Fifty Years of Rare Books and Special Collections at the University of Toronto (Exhibition and Catalogue by Richard Landon. Thomas Fisher Rare Book Library, University of Toronto, 26 September to 21 December 2005) (Toronto: University of Toronto Library, 2005), 8-18.

17. Geoffrey L. Stagg, "Years of Growth and Trial," in Kuitunen and Molinaro, 232-35, 235. Stagg was chair in 1956-66 and 1969-73.

18. Her thesis on Sforza Oddi and his Comedies was defended in 1932, and she was appointed to the faculty in 1947. On Corrigan, see Kuitunen and Molinaro, 36, 44-45; Robin Healey, From Cavalcanti to Calvino: 500 Years of Italian Editions and English Translations. An Exhibition in the Thomas Fisher Rare Book Library, University of Toronto, 13 May - 30 August 1996 (Toronto: University of Toronto Library, 1996), 7; Healey, From Aquinas to Atwood, 149. 
"continued to grow through acquisitions made possible by the Buchanan Fund [...] and through gifts from Professor Beatrice Corrigan and other donors. Early in 1968 the collection was strengthened considerably by a large acquisition from the Libreria Leo S. Olschki of Florence." ${ }^{19}$ The Renaissance holdings in RBSC were also augmented in the 1960s with transfers from the general collections, a normal practice started, as we saw, by Brown and which continues today. It is not uncommon for books to spend decades on the shelves of other libraries before making their way to the Fisher. In 1988, the writer of the present article was able to pull from the open stacks of Robarts and bring to a graduate seminar presentation on bibliography the editio princeps of the Vocabolario degli Accademici della Crusca, ${ }^{20}$ the first dictionary of the Italian language, published in 1612. It is now safely nestled among other treasures in the Fisher.

By the beginning of the 1970s, the renaissance of the University of Toronto had taken place and it had become a leading research institution with a first-class library. The last major event of the golden age occurred on April 13, 1973 with the opening of the Thomas Fisher Rare Book Library. It was named in honour of a nineteenth-century pioneer from Yorkshire, the great-grandfather of Sidney and Charles Fisher, twins who donated significant collections of Shakespeare and twentieth-century authors. Along with the Claude T. Bissell Building housing the Faculty of Information, the new Fisher structure was part a large architectural complex dominated by the John P. Robarts Research Library for the Humanities and Social Sciences. The complex is another of Bissell's great legacies, built in only five years at a cost of $\$ 42$ million. When it opened a few months after the Fisher, Robarts was the largest university library building in the world. It soon became known to students and to the Toronto media by the disparaging epithet "Fort Book," and it is still fashionable to speak of it as an architectural blight on the cityscape. Although the structure is certainly not possessed of great elegance, the judgment is unfair and rather philistine. There are more radical examples of Brutalist architecture in the city and on campus-Sidney Smith Hall is a short walk away-and anyone who has looked up from the desks of the reading room of the Fisher into the atrium rising five stories up to the ceiling can attest to the presence of beauty in the place. A point that is often ignored is that the buildings are perfectly suited to their primary 
function of conserving printed and other material and making it available for consultation. But the supreme fact, which ought to be remembered every time Robarts is mentioned, is that the complex holds two of the best libraries in the world and that it is one of the great repositories of human knowledge.

The opening of the Fisher and of Robarts brought to a close the second phase in the history of the University Library and opened the third. If the first had been marked by fire, and the second by plenty, this one was to be characterized by sustained growth and increasing prestige but also by declining funding. The opening coincided with the establishment in 1973 of the Department of Italian Studies as an independent academic unit, one which went on to experience considerable expansion at both the undergraduate and graduate levels. The staff of the libraries supported the programs and research agenda of the new department with their typical vigour, but they did so in a different environment. Government funding of universities began a long and relentless decline in the 1970s and library budgets were among the first to suffer. When Richard Landon was named director of the Fisher Library in 1976, the task was much more demanding than it had been for his predecessors. He proved up to the challenge. Under his stewardship, the Fisher's collections and its reputation grew steadily. When he joined its staff as a cataloguer in 1967, RBSC held about forty thousand items; ${ }^{21}$ when he died in 2011, still director, the number had passed seven hundred thousand. Landon was ahead of his time, at least for Canadian university administrators, in attracting private benefactors. It was a solution to the budget crisis facilitated by his talent in nurturing long-term relationships with collectors, patrons, and booksellers, and motivated by his dedication to the library. ${ }^{22}$

During his term, Italian Renaissance books entered the Fisher's collections by way of several gifts and bequests. Hannibal Noce was a professor in the Department of Italian Studies from 1966 to 1980, a respected textual critic and a bibliophile with an important and large collection of editions of the sixteenth, seventeenth, and eighteenth centuries. He donated most of his books to the Fisher after his retirement. ${ }^{23}$ In 1985, the library received the large

21. Landon, Bibliophilia, 14.

22. See Landon's obituary: Sandra Martin, "He built UofT's vast rare book collection," The Globe and Mail, 23 October 2011, http://utlibrarians.files.wordpress.com/2011/10/deaths-the-globe-and-mail.pdf. 23. Domenico Pietropaolo, “In memoriam: Hannibal Sergio Noce (1915-2001)," Quaderni d'italianistica 22.1 (2001): 5-6. 
bequest of Gilbert Bagnani, an Italian studies collection with many examples of fine Renaissance printing. ${ }^{24}$ In 2001, Karol Godlewski and his family donated the Polish and Italian books put together by his uncle, Count Emeryk Hutten Czapski, a statesman from a distinguished Polish house. The collection included rare Italian imprints. Among other donations that brought Renaissance books can be counted the gift of the philosophy collection of Michael Walsh, the Stillman Drake gifts of Galileo and history of science material, and gifts from Harvey J. Olnick. Among the bequests were the T. G. H. Drake Collection of pediatric books (1961), and books from J. E. Shaw (1963) and Beatrice Corrigan (1977). ${ }^{25}$

One of the most recent and certainly the most significant source of support for acquisitions is the Emilio and Emma Goggio Fund for Italian Studies. Goggio was another key member of the faculty in Italian at Toronto. He was appointed instructor in 1909, professor in 1920, and chair in 1946, serving until his retirement ten years later. In 1995, his family established in his memory and that of his wife the Emilio Goggio Chair in Italian Studies, and in 1997 it endowed the book fund. The income from the Goggio Fund and from the Buchanan Fund both contribute to the purchase of rare books, but the amounts generated by the former are much larger.

The continued growth of the holdings of Renaissance rare books is complemented by the systematic development of the general collection in the Robarts Library, one of the largest and most comprehensive concentrations in the field. Amilcare Iannucci's assessment of its value for Italianists still holds true three decades later: "In 1984 [...] the Italian collection at the Robarts Research Library was among the very best in North America, the legacy of a continuous and prestigious tradition of Italian Studies at the University of Toronto which reached back to the middle of the last century." ${ }^{26}$

All libraries are shaped by historical conditions and by the interests, passions, and competence of individual collectors, librarians, donors, and scholars. As this sketch has attempted to illustrate, the Fisher's Italian Renaissance

24. On these books, see Ex Bibliotheca Vogriana Gilberti Bagnani: An Exhibition of Books from the Bequest of Gilbert Bagnani (Toronto: Thomas Fisher Rare Book Library, University of Toronto, 1987).

25. Robin Healey gives a succinct overview of the gifts, bequests, and endowments in Italian Studies to the University Library in the "Introduction" to the catalogue of his exhibition From Aquinas to Atwood, 11-17. 26. Amilcare Iannucci, "Forging New Links," in Kuitunen and Molinaro, 241. Iannucci was a Dante scholar and chair of Italian Studies in the 1980s. 
collections are the fruit of 125 years of acquisitions made by the University Library under the guidance of the faculty in Italian and in support of their department's research priorities, together with government funding, endowments, and gifts and bequests of books made by private and academic collectors with diverse bibliographic and cultural interests.

We can now turn to a closer examination of the Fisher's Italian Renaissance books. There is no easy way to survey, categorize, and describe these volumes. The challenge is threefold: the richness and breadth of the material, the ease with which Renaissance texts cross boundaries of genre, and the inconvenient fact that the items from that period are scattered throughout the library's collections. With some exceptions, I will restrict myself to books printed in Italy, in any language, up to 1600. It is self-evident that a vast range of texts printed outside the peninsula during this period-as well as just before and for some time after-also falls within the scope of the Italian Renaissance. Without entering into questions of periodization and definition typical of the field, I will only note that traditional geographical and chronological demarcations are practical and liberating when time, space, and the energies of the writer are limited. For each of the sections that follow, I will provide representative examples of books significant for their content or for their bibliographical value, though it must be emphasized that the selection is illustrative and that each section might easily have included a good number of other important items.

The major strengths of the Italian Renaissance holdings are in the areas of literature, history, science and medicine, and the history of books. It can be said without hesitation that the greatest strength lies in sixteenth-century literature in the vernacular, that is, in Italian. The library's collection covers the full range of genres and includes important editions of the major literary works of the period. What we see in this rich resource for scholarly research is the affirmation of a "national" literature in the vernacular, a tradition with roots in the late Middle Ages but which became established, theorized, and celebrated in the Cinquecento.

The Fisher has excellent holdings of editions of lyric verse, one of the most popular and influential genres of the new literature. As has already been noted above, poetry represents one of the oldest concentrations of Italian books in the library, and one which has been continuously expanded since the first accessions at the end of the nineteenth century. These books are for the most part in the Rime collection but they can also be found in the Buchanan and 
Drake holdings. ${ }^{27}$ Francesco Petrarca, the supreme model for Cinquecento lyric poets, is present in almost thirty collections of verse, including Il Petrarca issued in 1533 by the heirs of the scholar-printer Aldus Manutius, and several editions of Il Petrarca by Gabriele Giolito. ${ }^{28}$ This Venetian publisher-printer did much to establish Italian verse as a mainstay of the book market, especially with innovative collections of anthologies edited by the poligrafi Ludovico Dolce and Ludovico Domenichi. The principal poets figure in anthologies or single-author editions, many of which are first editions: Pietro Bembo, Vittoria Colonna, Tullia d'Aragona, Giovanni Della Casa, Gian Giorgio Trissino, Pietro Aretino, Benedetto Varchi, Laura Battiferri, Vincenzo Martelli, and Gaspara Stampa. ${ }^{29}$ The presence of women Petrarchists is an indication of one of the radical innovations of Cinquecento literature, which by virtue of being written in the vernacular and in accessible forms such as the sonnet allowed into the ranks of authorship entire categories of individuals formerly excluded by the barriers of Latin and formal humanist training.

The Fisher's collection of Renaissance drama is one of the largest in North America and is considered one of the best in the world..$^{30}$ As we have seen, its beginnings can be dated to the European trip undertaken in 1922 by Hugh Hornby Langton. It is concentrated in the Italian Play Collection, a major resource for scholars of theatre, consisting of about ten thousand titles including post-1600 items. Ariosto and Bernardo Dovizi developed neoclassical comedy on the models, freely adapted, of Plautus and Terence. Their innovations are available in Toronto in several editions, including early examples of Ariosto's I Suppositi and La Lena, and five editions of Dovizi's La Calandra. ${ }^{31}$ The first neoclassical

27. On the Rime collection, see the still useful Molinaro, A Bibliography of Sixteenth-Century Italian Verse Collections. It lists 115 editions.

28. Il Petrarca (Venice: Heirs of Aldus and Andrea Torresano, 1533).

29. First editions include: G. G. Trissino, Rime (Vicenza: Tolomeo Gianicolo, 1529); G. Della Casa, Rime et prose (Venice: Niccolò Bevilacqua, 1558); V. Martelli, Rime e lettere (Florence: Giunta, 1563); Gaspara Stampa, Rime di Madonna Gaspara Stampa (Venice: Plinio Pietrasanta, 1554).

30. See Beatrice M. Corrigan, Catalogue of Italian Plays; "Italian Renaissance Plays," Renaissance News 16.4 (1963): 298-307; "Italian Renaissance Plays in the University of Toronto Library," Renaissance News 19.3 (1966): 219-28; "Italian Renaissance Plays in the University of Toronto Library: Supplement III," Renaissance Quarterly 27.4 (1974): 512-32.

31. Ariosto, I Suppositi (Venice: Bindoni and Pasini, 1526) and La Lena (Venice: Zoppino, 1535). The earliest edition of Dovizi’s La Calandra is: Venice, Francesco Bindoni \& Maffero Pasini, 1547. 
tragedy to be written was Gian Giorgio Trissino's La Sofonisba, of which the Fisher holds the 1529 quarto printed in Vicenza by Tolomeo Gianicolo. The first "regular" tragedy to be produced was Giovanni Battista Giraldi Cinzio’s Orbecche (in 1541, while the Sofonisba was produced only in 1554). The library holds the 1552 and 1583 editions, among Giraldi Cinzio's various tragedies. ${ }^{32}$ Other important playwrights present in the Italian Play Collection are Dolce, Aretino, Girolamo Parabosco, Anton Francesco Grazzini, Giovanni Maria Cecchi, and Angelo Beolco, known as il Ruzzante. The Florentine Cecchi wrote both comedies and religious plays, and the latter were the subject of Konrad Eisenbichler's dissertation. ${ }^{33}$ Among its collection of manuscripts, the Fisher counts the only known version of an anonymous sixteenth-century comedy entitled Il Capriccio, probably by a member of the Accademia degli Intronati or the Congrega dei Rozzi in Siena. It was first published in a critical edition by Michael Lettieri and Julius A. Molinaro, professors at the University of Toronto. ${ }^{34}$

The Fisher owns two copies of the editio princeps of Battista Guarini's Il Pastor Fido, a masterpiece of pastoral drama. ${ }^{35}$ It also holds a first edition of Ottavio Rinuccini's La Dafne, printed in Florence by Giorgio Marescotti in 1600. This is the earliest known libretto of what is considered to be the first opera, originally performed in 1598, though the music by Jacopo Peri and Jacopo Corsi has been mostly lost. The library also owns the princeps of L'Euridice, the first opera for which the music survives; it too was composed by Peri, and the libretto was again by Rinuccini. ${ }^{36}$ Although the material lies beyond the chronological limits of this article, it is useful to mention that in addition to the

32. G. B. Giraldi Cinzio, Orbecche (Venice: Gabrile Giolito, 1552); the latter edition is in Le Tragedie (Venice: Cagnacini, 1583).

33. “The Religious Drama of Giovan Maria Cecchi” (PhD dissertation, University of Toronto, 1981).

34. Michael Lettieri and Julius A. Molinaro, eds., Il Capriccio: commedia anonima del Cinquecento (Welland, Ontario: Éditions Soleil, 1999). See also Beatrice M. Corrigan, "Il Capriccio: An Unpublished Italian Renaissance Comedy and Its Analogues," Studies in the Renaissance 5 (1958): 74-86. The manuscript, now MSS 06600, was formerly catalogued as MSS itp 00002. See also Michael Lettieri, "Per l'edizione del Capriccio, una commedia anonima del Cinquecento," in Pluralism and Critical Practice: Essays in Honor of Albert N. Mancini, ed. Paolo A. Giordano and Anthony J. Tamburri (West Lafayette, IN: Bordighera Press, 1999), 194-201; Michael Lettieri, "Note sull'epilogo del Capriccio (sec. XVI) e su una probabile fonte figurativa utilizzata in chiave parodica," Studi Italiani 19.1 (2007): 91-102.

35. Il pastor fido, tragicomedia pastorale (Venice: G.B. Bonfadino, 1590). The gift of Harvey J. Olnick in 1989; see Healey, From Aquinas to Atwood, 86.

36. Florence: Cosimo Giunta, 1600. 
several hundred seventeenth- and eighteenth-century librettos in the Italian Play Collection, the Fisher's Libretti Collection of post-1815 operas consists of over four thousand titles.

Narrative poetry was another genre which came to characterize Italian literature in the Cinquecento. While drawing from the rich tradition of chivalric romance, which stretched back to the Middle Ages, authors of the period bent the genre towards epic forms, revealing the deeper ambitions of the nascent vernacular culture. The masterpiece was Ariosto's Orlando Furioso, a bestseller printed in at least 170 editions in sixteenth-century Italy, more than any other title, vernacular or Latin. The Fisher owns copies of a dozen editions. The ones printed by Giolito feature an elegant set of woodcut illustrations, one for each of the forty-six cantos. ${ }^{37}$ Another fine set of cuts graces the editions by Vincenzo Valgrisi, which first appeared in 1556 in both quarto and octavo, and the library owns copies in both formats. ${ }^{38}$ From the Bagnani bequest comes a copy of the De Franceschi edition of 1584, an outstanding example of late Renaissance Venetian printing with a set of engravings by Girolamo Porro. ${ }^{39}$ Copies of the Porro plates adorned the first translation into English of Ariosto's poem, printed by Richard Field in London in 1591 and again in $1607 .{ }^{40}$ Both folios are present in the Fisher, and they have been the object of close analysis by Randall McLeod, a long-time member of the Department of English who published his findings in a number of pseudonymous publications. ${ }^{41}$ This verse translation had an important influence on Elizabethan literature. It was the work of Sir John Harington, a poet and a favourite of Queen Elizabeth I, who is also

37. Orlando furioso, con alcune stanze, et cinque canti d'un nuouo libro (Venice: G. Giolito, 1550); Orlando furioso con la giunta di cinque canti (Venice: G. Giolito, 1555-56).

38. Orlando furioso (Venice: V. Valgrisi, 1556), in quarto (shelf-mark D-10 00457); Orlando furioso (Venice: V. Valgrisi, 1556), in octavo (shelf-mark B-12 00019). The latter was in the collection of Gilbert Bagnani.

39. Orlando furioso ... nuouamente adornato di figure di rame da Girolamo Porro (Venice: Francesco De Franceschi, 1584).

40. Orlando furioso in English heroical verse.

41. Orlando F. Booke, "IMAGIC-a long discourse," Studies in the Literary Imagination 32.1 (1999): 190-215; Random Cloud, "from Tranceformations in the Text of Orlando Furioso," The Library Chronicle of the University of Texas at Austin 20.1/2 (1990): 60-85; Randall Mc Leod, “The Fog of arT”, in Exercices furieux: partir de l'édition de l'Orlando furioso De Franceschi (Venise, 1584), ed. Ilaria Andreoli (Bern: Peter Lang, 2013), 163-247. 
credited with the invention of the flush toilet. Ariosto's classic was technically a continuation of Matteo Maria Boiardo's Orlando Innamorato, a chivalric poem available in Toronto in the 1539 Milanese reissue of an earlier edition, as well as in the rifacimento by Francesco Berni printed in $1545 .{ }^{42}$ The epic that eventually challenged the Furioso's popularity and critical standing was Torquato Tasso's Gerusalemme Liberata. The Fisher holds several significant early versions of this poem, including the Ferrara edition by Vittorio Baldini and the Casalmaggiore edition published by Antonio Canacci and Erasmo Viotti, both dated 1581. The library also owns a first edition of Tasso's preferred version, the Gerusalemme Conquistata (Roma, Facciotti, 1593), as well as the first edition of Edward Fairfax's translation into English verse, Godfrey of Bulloigne. ${ }^{43}$ The availability of the Ariosto and Tasso texts in both the original Italian and the English translations is a vivid example of how the Fisher's substantial collection of English Renaissance literature complements the Italian holdings, affording scholars who are interested in the currents of influence between the two cultural traditions valuable research opportunities. ${ }^{44}$

Lyric poetry, drama, and chivalric epic were only three of a wide range of genres taken on by the vernacular literature of the Italian Renaissance. The richness and complexity of the literary culture of the time is illustrated by the versatile production of the major authors. Niccolò Machiavelli's writings span political theory, history, theatre, the science of war, and poetry. In the Walsh Collection is a copy of the Discorsi sopra la prima deca di Tito Livio printed in Florence by Bernardo Giunta. This second edition of the secretary's major work was published on 10 November 1531, less than a month after the editio princeps produced in Rome by Antonio Blado. Toronto also owns editions of

42. The quarto edition Tutti li libri de Orlando inamorato (Milan, 1539) is a re-issue by G. A. da Castiglione of a lost edition printed by G. A. Scinzenzeler between 1513 and 1518. See Neil Harris, Bibliografia dell'Orlando Innamorato, 2 vols. (Modena: Panini, 1988-91), 1:55-59; Orlando innamorato composto gia dal sig. Matteo Maria Bojardo, conte di Scandiano, ed hora rifatto tutto di nuovo da Francesco Berni (Venice: Heirs of Lucantonio Giunta, 1545).

43. Di Gerusalemme conquistata libri XXIIII (Roma: G. Facciotti, 1593); Godfrey of Bulloigne, or, The Recouerie of Ierusalem: Done into English Heroicall Verse (London: Ar. Hatfield for John Jaggard and M. Lownes, 1600).

44. The influence of Italian on English literature was the theme of Robin Healey's From Cavalcanti to Calvino in 1996. 
the Libro dell'arte della guerra and Il principe. ${ }^{45}$ The cardinal, poet, and philosopher Pietro Bembo is another dominant figure whose multifaceted writings are well represented in the collections. Among works such as the Rime and De Aetna, the Fisher counts an early edition of his dialogues on love, Gli asolani, and eight editions of the Prose della volgar lingua, including the editio princeps of $1525 .{ }^{46}$ The Prose was the landmark historical grammar that enshrined the literary Florentine of Petrarch and Boccaccio as models, respectively, for verse and prose composition. In addition to innovations in drama and narrative poetry, Ariosto made a contribution to another genre with his satires, which were influenced by Horace; his Satires are present here in an early edition. ${ }^{47}$ Baldassarre Castiglione's immensely influential Il libro del Cortegiano is at once a dialogue and treatise on the subject of the perfect courtier, an elegiac portrayal of an aristocratic society on the wane, and a brilliant expression of the refined civilization of the High Renaissance. The Fisher's eight sixteenth-century editions are crowned by a copy of the princeps by the heirs of Aldus Manutius, a beautiful folio printed in $1528{ }^{48}$ The poet, archbishop, and inquisitor Giovanni Della Casa is best known for the Galateo, a courtesy book more closely on topic but no less successful over the centuries than the Book of the Courtier. It was first printed in 1558 as part of the author's Rime et prose, one of five sixteenthcentury editions present here. ${ }^{49}$

By mid-century, vernacular literature had established itself and was beginning to challenge the hegemony of Latin. Scholars, some of whom were poets themselves, now turned to the task of analyzing Italian texts and classifying them into genres. In pursuit of this project, they came to rely increasingly on Aristotelian poetics, eventually marrying this theoretical approach to post-Tridentine orthodoxy. The Fisher holds a large collection of the literary criticism and theory of this period. Early critical milestones found in the

45. Libro dell'arte della guerra (Venice: Domenico Giglio, 1554); Il principe (Venice: D. Giglio, 1554).

46. Gli asolani (Venice: Aldus, 1515); Prose di m. Pietro Bembo nelle quali si ragiona della volgar lingua (Venice: Giovanni Tacuino, 1525).

47. Le Satire (Venice: Niccolò Zoppino, 1535).

48. Il libro del cortegiano (Venice: Heirs of Aldus and Andrea Torresano, 1528). The volume was purchased in 1968 with funds from the Buchanan Fund (Healey, From Aquinas, 123). On the Fisher copy, see Random Cloud, "Where angels fear to read," in $\mathrm{Ma}(r)$ king the Text: The Presentation of Meaning on the Literary Page, ed. E. Bray, M. Handley, and A. C. Henry (Aldershot: Ashgate, 2000), 144-92.

49. Rime, et Prose (Venice: Niccolò Bevilacqua, 1558). 
library are the Discorsi by Giraldi Cinzio and I romanzi by his student Giovan Battista Pigna. ${ }^{50}$ The two treatises were the expression of a bitter polemic over the proper theoretical approach to contemporary literature. The literary debate in the middle decades of the Cinquecento centred on the interpretation of the Orlando Furioso, but the appearance of the Gerusalemme in 1581 heralded a long and complicated querelle over the question of which of the two works was superior. First among the proponents of Tasso was Camillo Pellegrino, ${ }^{51}$ whereas the apologists of Ariosto included Leonardo Salviati and other members of the Accademia della Crusca, which was founded in 1583 in Florence with the high mission of preserving the purity of the Italian language. ${ }^{52}$ Tasso himself joined the debate with his Apologia..$^{53}$ These texts represent a detailed record of the reception of particular literary works, of the character of the literary culture of the day, and of the ways in which a European canon was first formulated.

As poets added to the store of works in the vernacular and scholars developed the related critical apparatus, the idea gradually emerged that contemporary texts might aspire to the same dignity as classical literature. But the writers and critics of the Cinquecento did not seek a radical newness entirely removed from the past. They worked in constant dialogue with the medieval and classical traditions, in the spirit of dynamic imitation. Dante, Petrarch,

50. G. B. Giraldi Cinzio, Discorsi intorno al comporre dei romanzi, delle comedie, e delle tragedie, e di altre maniere di poesie (Vinegia: G. Giolito, 1554); G. B. Pigna, I romanzi (Venice: Valgrisi, 1554).

51. Pellegrino's dialogue Il Carrafa, o vero della epica poesia was appended (121-74) to Parte delle rime di D. Benedetto dell'Uva, Giovanbatista Attendolo, et Cammillo Pellegrino. Con un brieve discorso Dell'Epica Poesia (Florence: Bartolomeo Sermartelli, 1584/1585).

52. The Fisher's holdings include: Leonardo Salviati (attributed), Degli accademici della Crusca difesa dell'Orlando furioso dell'Ariosto, contra'l Dialogo dell'epica poesia di Cammillo Pellegrino. Stacciata prima (Florence: D. Manzani, 1584 [colophon: G. Marescotti]); Salviati, Dello Infarinato, accademico della Crusca, Risposta all'Apologia di Torquato Tasso intorno all'Orlando furioso, e alla Gierusalè liberata (Florence: C. Meccoli and S. Magliani, 1585). The Fisher also has other editions of these two titles, as well as Salviati, Lo'Nfarinato secondo, ovvero, Dello'Nfarinato accademico della Crusca, risposta al libro intitolato Replica di Camillo Pellegrino ec. nella qual risposta sono incorporate tutte le scritture, passate tra detto Pellegrino, e detti accademici intorno all'Ariosto, e al Tasso, in forma, e ordine di dialogo. Con molte nuove quistioni di poesia, e loro discioglimenti, e con la tavola copiosissima (Florence: A. Padovani, 1588).

53. Apologia del sig. Torquato Tasso in difesa della sua Gierusalemme liberata, con alcune altre opere, parte in accusa, parte in difesa dell'Orlando furioso dell'Ariosto, della Gierusalemme istessa, e dell'Amadigi del Tasso padre (Ferrara: Giulio Cesare Cagnacini et fratelli, 1585). 
and Boccaccio, "the three crowns" of Italian literature, were particularly significant to the evolving literary consciousness, and editions of their works are well represented in the Fisher's collections. The holdings of Dante's Commedia include the famous Aldine of 1502, edited by Pietro Bembo on the basis of a manuscript given as a gift by Boccaccio to Petrarch. ${ }^{54}$ The text of the poem established by Bembo remained authoritative until the nineteenth century. This book and the copy of the 1515 edition of the Commedia also at the Fisher are both examples of Aldus's famous enchiridia, or handbooks, exquisite octavos printed in the italic typeface cut for him by Francesco Griffo. ${ }^{55}$ The library also holds the folio printed in 1491 by Petrus de Plasiis, with Cristoforo Landino's commentary and numerous woodcut illustrations. This copy was the gift of Milton Buchanan in 1950; he had purchased it in 1908 for $£ 126 s .{ }^{56}$ In addition to the titles already mentioned above, the Petrarch books include the Trionfi of 1478 with the commentary by Bernardo Lapini, and the folio edition of the Trionfi e Canzoniere of 1484 with the commentaries of Lapini, Francesco Filelfo, and Girolamo Squarciafico. ${ }^{57}$ The Fisher also holds the first Italian edition of Petrarch's De remediis utriusque fortunae, with the authoritative text established by Niccolò Lucano. ${ }^{58}$ Among the works of Boccaccio, the 1514 folio edition of the Philocolo and the illustrated quarto of Il Decamerone printed in 1548 and edited by Francesco Sansovino stand out. ${ }^{59}$ The latter book belonged to Sir Thomas Lucy (1583-1640), an important collector of French and Italian books, and is annotated throughout in an italic hand. Acquired in 1970, it "provides one of the many links in the Fisher Library collections between Italian and English Literature." ${ }^{60}$

54. Le terze rime di Dante (Venice: Aldus Manutius, 1502).

55. Dante col sito, et forma dell'inferno (Venice: Nelle case d'Aldo et d'Andrea di Asola, 1515); title leaf wanting.

56. La commedia (Venice: Petrus de Plasiis, 1491). Healey, From Aquinas to Atwood, 24-25.

57. Trionfi (Venice: Reynaldus de Novimagio and Theodorus de Reynsburch, 1478); Trionfie Canzoniere (Venice: Petrus de Plasiis, 1484).

58. Petrarca, De remediis utriusque fortunae (Cremona: Bernardinus de Misintis and Caesar Parmensis, 1492).

59. Philocolo in lingua vulgare tosca (Venice: Agostino Zani, 1514); Il Decamerone (Venice: G. Giolito, 1548).

60. Landon, Bibliophilia, 115-16. 
The emergence of vernacular literature occurred within a cultural system that was still defined by Latin and the humanist rediscovery of classical texts, and even after Italian had affirmed itself the classical tradition continued to exert a powerful influence on Italian culture and was dominant in areas such as the law and science. Scholarly editions and translations of ancient Latin and Greek authors as well as the works of fifteenth- and sixteenth-century humanists remained a mainstay of publishers' catalogues, a fact reflected in the collections of the Fisher and best illustrated if we proceed by discipline, beginning with philosophy. The large Aristotle Collection offers a good indication of the classical and humanist dimension. Its Latin editions of the philosopher range from the folio of the Organon printed in 1481 to the octavo edition of the Works published by the Giunta in $1573 .{ }^{61}$ It includes Renaissance commentaries such as Pietro Vettori's on the Rhetoric, ${ }^{62}$ as well as translations such as Bernardo Segni's rendering of the Politics, the Rhetoric, and the Poetics. ${ }^{63}$ The Walsh Philosophy Collection, presented to the Fisher by Michael and Virginia Walsh, is a major encyclopedic collection covering the philosophical tradition of the West from classical Greece to the current day. Among its sixteenth-century books is Pietro Pomponazzi's Tractatus acutissimi and a copy of the first Aristotle edition prepared by his student Marcantonio Zimara, a Latin edition of the Metaphysics. ${ }^{64}$ Among the Walsh incunables are copies of the first edition of the first part of Thomas Aquinas's Summa Theologica, printed in 1473, ${ }^{65}$ and the 1475 edition of his Summa contra gentiles, ${ }^{66}$ printed by Arnoldus Pannartz. Along with Konrad Sweynheym, Pannartz is credited with bringing the art of printing with movable types to Italy. These are two examples of the fifty or so Renaissance editions of Aquinas in the Fisher, an indication of the importance of Thomism during the period. The general philosophy collections are also a source of classical editions, with items such as a 1512 Lucretius, a translation of

61. Organon (Venice: Filippo di Pietro, 1481); Aristotelis omnia quae extant Opera (Venice: Giunta, 1573), volume 5 of 16.

62. Petri Victorii Commentarii in tres libros Aristotelis De arte dicendi (Florence: Giunta, 1548).

63. Trattato dei governi (Florence: L. Torrentino, 1549); Rettorica, et Poetica d'Aristotile (Florence: Torrentino, 1549).

64. Tractatus acutissimi (Venice: Ottaviano Scoto, 1525); Aristotle, Aristo. Stagyri. Lib. Metaphysi. XII (Pavia: Giacomo Pocatela, 1521).

65. Summa theologicae: pars prima (Padua: Albertus de Stendal, 1473).

66. Summa contra gentiles, sive De veritate Catholicae fidei (Rome: Arnoldus Pannartz, 1475). 
Seneca's De Beneficiis by the poet and historian Benedetto Varchi, ${ }^{67}$ and three editions of the Dialoghi di amore by Leone Ebreo (Judah Leon Abravanel). ${ }^{68}$ This treatise on love drew upon both Renaissance Platonism and Jewish philosophy. It became very influential in the sixteenth century and is an example of the manifold nature of Renaissance thought.

When we turn to history, we find that Toronto owns works by a representative range of classical authors, including an Italian translation of Thucydides's History of the Peloponnesian War, ${ }^{69}$ the first Italian edition of Xenophon's Anabasis, ${ }^{70}$ an early folio of Livy, ${ }^{71}$ and a 1508 edition of Caesar's Commentaries. ${ }^{72}$ Among the modern historians, the library counts editions by Leonardo Bruni, Flavio Biondo, Paolo Giovio, Francesco Guicciardini, and Machiavelli, including the 1546 Aldine of the Florentine Histories, ${ }^{73}$ as well as works by minor figures such as Cesare Campana, Girolamo Falletti, and Giovanni Tarcagnota. Under the general rubric of literature we can list the Fisher's holdings of classical Greek authors, among which there are both Greek and Latin editions of Homer, including the Aldine of $1524,{ }^{74}$ and copies of the editiones principes of Sophocles and of Euripides. ${ }^{75}$ The library also owns a good range of Roman authors. Virgil, Cicero, Ovid, and Horace, for example, are found in both Latin editions and Italian translations, including the version of Cicero's De oratore

67. Lucretius, De rerum natura libri VI (Florence: Filippo Giunta, 1512); Seneca, De benefizii tradotto in volgar fiorentino (Florence: Torrentino, 1554).

68. The Buchanan Collection includes two editions of the Dialoghi: Venice, Heirs of Aldus, 1552, and Venice, Niccolò Bevilacqua, 1572. The third (Venice: Domenico Giglio, 1558) was among the first books purchased in 1998 with the support of the Goggio Fund.

69. Thucicide Historico greco delle guerre fatte fra i popoli della Morea et gli Atheniesi tradotto dal greco per Francesco di Soldo Strozzi (Venice: G. Giolito 1564).

70. I sette libri di Xenophonte della impresa di Ciro minore; tradotti per M. Lodovico Domenichi (Venice: Gabriel Giolito, 1547). This book entered the Fisher in 1998, as part of the first acquisitions made with funds from the Goggio bequest.

71. Historiae Romanae decades (Milan: Filippo Cavagni di Lavagna, 1478).

72. Commentaria Caesaris (Florence: Filippo Giunta, 1508).

73. Historie di Nicolò Machiauelli, cittadino, et secretario fiorentino (Venice: Heirs of Aldus, 1546).

74. Vol. 1: Homeri Ilias; Vol. 2: Vlyssea, Batrachomyomachia, Hymni XXXII (Venice: Heirs of Aldus and Andrea Torresano, 1524).

75. Sophoclis Tragaediae Septem (Venice: Aldus, 1502); Euripidis tragoediae septendecim (Venice: Aldus, 1503). 
by Ludovico Dolce. ${ }^{76}$ The edition of Ovid's Fasti in the collection is the first Italian translation, carried out by Vincenzo Cartari. ${ }^{77}$ Along with other editions, the poets Catullus, Tibullus, and Propertius are available in two copies of the Aldine octavo of $1502 .^{78}$

Classical and humanist texts are found in other subject areas, including architecture, antiquarianism, and travel literature. The Fisher owns a copy of Cosimo Bartoli's translation of Leon Battista Alberti's De re aedificatoria ${ }^{79}$ a folio of the 1567 edition of Vitruvius's De architectura with Daniele Barbaro's commentary, and a later quarto with Barbaro's Italian translation of the same text. ${ }^{80}$ There is also a significant collection of guidebooks of Rome, many from the Gilbert Bagnani bequest. ${ }^{81}$ These books are a fascinating source of evidence for all kinds of historical investigation-topography, archaeology, architecture, art history, travel, religious practices. The highlights here are a Latin edition and an Italian translation of De Roma Instaurata and De Italia Illustrata by Flavio Biondo, the pioneer of antiquarian scholarship. ${ }^{82}$ The literature of travel and exploration was the subject of a memorable exhibition by Robin Healey, ${ }^{83}$ which included Ptolemy's Geography in Girolamo Ruscelli's translation as well as an edition of Ignazio Danti's treatise on the astrolabe, the first book to be published in Italy on the use and manufacture of the instrument. ${ }^{84} \mathrm{On}$

76. Il dialogo dell'oratore (Venice: Gabriele Giolito, 1547).

77. I fasti di Ovidio (Venice: Francesco Marcolini, 1551). In two copies, the first from the Buchanan collection (buc 00407), the second acquired with Goggio funds (B-12 8582 RBSC).

78. Catullus. Tibullus. Propertius (Venice: Aldus, 1502).

79. L’Architettura (Venice: Francesco De Franceschi, 1565).

80. Vitruvius Pollio, De architectura libri decem, cum commentariis Danielis Barbari (Venice: Francesco De Franceschi \& Johann Criegher, 1567); I dieci libri dell'architettura (Venice: Francesco De Franceschi, 1584).

81. See Amy Marshall, Mirabilia Urbis Romae: Five Centuries of Guidebooks and Views. An Exhibition Held at the Thomas Fisher Rare Book Library, University of Toronto, 28 January - 26 April 2002, catalogue edited by Mary Garvie Yohn (Toronto: University of Toronto Library, 2002).

82. Blondi Flavii Forliviensis De Roma instaurata libri tres ... De Italia illustrata opus tum propter (Venice: Bernardino Vitali, 1503); Roma ristaurata, et Italia illustrata (Venice: Michele Tramezzino, 1543).

83. Robin Healey, Hopeful Travellers: Italian Explorers, Missionaries, Merchants and Adventurers from the Middle Ages to Modern Times: An Exhibition in the Thomas Fisher Rare Book Library, University of Toronto, 30 January - 27 April 2007 (Toronto: University of Toronto Library, 2007).

84. La geografia di Claudio Tolomeo Alessandrino (Venice: V. Valgrisi, 1561); Primo volume dell'uso et fabbrica dell'astrolabio, et del planisferio (Florence: Giunta, 1578). The latter is the second edition, 
the Fisher shelves also sits a copy of the 1598 Italian edition of the Ptolemy, with copper-engraved maps by Girolamo Porro, another item from the Bagnani bequest. ${ }^{85}$

The general category of theology and religion is well represented in the Fisher's collections. In addition to the Aquinas holdings already mentioned, there are examples of major texts such as the Dialogo della Divina Provvidenza, ${ }^{86}$ Saint Catherine of Siena's principal work, here in the third Italian edition. There are also less familiar texts such as the rare first edition of Giulio Landi's dialogues on religion and moral philosophy. ${ }^{87}$ In 2012, the library purchased Ecclesiae anglicanae trophaea, a book of engravings by Giovanni Battista Cavalieri after the series of lost frescoes of English saints and martyrs painted by Niccolò Circignani (Pomarancio) in the Venerable English College in Rome. It is a noteworthy Catholic response to John Foxe's Book of Martyrs. ${ }^{88}$ The Fisher also owns a number of papal bulls printed in the sixteenth century. Several are found in a sammelband of nineteen edicts printed in Bologna between 1555 and 1570, which brings together papal bulls, provisioni, and motu proprios, each with the woodcut coat of arms of a pope or cardinal on the title-page. These edicts, all very rare, range between mercantile and canon law and include a work on the census. ${ }^{89}$ The Knox College Collection of some five thousand rare books has been on deposit at the Fisher since 1995; particularly strong in reformed theology, it counts among its titles some Italian imprints. The Regis College Library has also placed on deposit its rare books, some of which were printed in Italy in the sixteenth century. Manuscript material of interest to scholars of religion is also collected by the library. A fifteenth-century manuscript of an Italian translation of the De Imitatio Christi, the popular text attributed to

following that of 1569 .

85. Geografia, cioè, Descrittione universale della terra (Venice: Giovanni Battista and Giorgio Galignani, 1598).

86. Dialogo de la seraphica virgine sancta Catherina da Siena della divina prvidentia (Venice: Matteo Capcasa for Lucantonio Giunta, 1483, but 1494). Purchased with funds from the Goggio endowment.

87. Le attioni morali dell'illust. Sig. Conte Giulio Landi (Venice: Gabriele Giolito, 1564).

88. Niccolò Circignani, Giovanni Battista Cavalieri, Ecclesiae anglicanae trophaea sive Sanctorum martyrum, qui pro Christo catholicaeque fidei veritate asserenda, antiquo recentiorique persecutionum tempore, mortem in Anglia subierunt, passiones Romae in Collegio Anglico (Rome: Bartolomeo Grassi, 1584). I am grateful to Scott Schofield for pointing me to this remarkable counter-Reformation item. 89. The volume bears the shelf-mark B-13-00538. It was purchased with Goggio funds in 2003-04. 
Thomas à Kempis, is adorned with ornamental initials and illuminated borders and initials. ${ }^{90}$ A group of eight late-sixteenth and early-seventeenth-century manuscripts concerned with papal politics and with the struggle against the Turks, acquired in 2000 and 2001 with support from the Goggio Fund, includes instructions from Pope Julius III to Pietro Camaiani, nuncio extraordinary to the court of Emperor Charles V,91 and an account of the Council of Trent by the Venetian Antonio Milledonne. ${ }^{92}$

The collections of Hebraica and Judaica are another significant resource for Renaissance studies. The Friedberg Collection of Hebrew manuscripts and early printed books holds a good number of incunables and sixteenth-century books printed in Italy. These include several editions printed by the Soncino, a family of printers active in several Italian cities and in Costantiniple, an early example being the 1485 edition of the Former Prophets with the commentary by David Kimhi. ${ }^{93}$ The Friedberg books also include a copy of the Makre dardeke, the important Hebrew-Arabic-Italian dictionary printed at Naples in $1488,{ }^{94}$ and a copy of Abraham de Balmes's Hebrew grammar issued by the Venetian press of Daniel Bomberg in 1523. ${ }^{95}$

The Fisher Library's collections in the history of science and the history of medicine are exceptional. The scientific culture of the Renaissance leading up to Galileo is a particular area of strength of the general science collection,

90. "Dell'immitatione di Cristo" (Venice?: ca. 1460-80) (shelf-mark: MSS 03265). The manuscript was bought in May 2013 by the Fisher with a significant contribution from the Goggio Fund. Miguel Torrens provided me with information on acquisitions made since 2010 with the support of the Goggio Fund.

91. Pope Julius III, "Instruttione data a Piet.o Camaiani nostro Camr. alli x. di Ottobre 1551 per lo Imperat.re" (shelf-mark MSS gen 13.006). A manuscript of thirty-five pages. Robin Healey provided me with information about acquisitions made through the Goggio Fund to 2004.

92. "Historia del Sacro Concilio di Trento scritta per mano di M. Antonio Milledoni secret.rio del Conso. di X Prefatio" (shelf-mark MSS 05306). The manuscript of 560 pages dates to the late sixteenth century. It is one of the first records of the Council to be written and was used by Paolo Sarpi in his own history of Trent. It is unpublished, though an abbreviated version appeared in French in 1870, edited by Armand Baschet. Milledonne (1522-88) accompanied the Venetian representatives to the Council of Trent in 1562-53 and was later secretary to the Venetian Council of Ten. Book 1 of 2, it deals mainly with the historical background to the Council.

93. Nevi'im rishonim 'im perush Radak (Soncino: Joshua Solomon Soncino, 1485).

94. Naples: Joseph ben Jacob Ashkenazi Gunzenhauser, 1488.

95. Abraham ben Meir de Balmes, Mikneh Avram = Peculium Abrae. Grammatica Hebraea una cum Latino (Venice: Daniel Bomberg, 1523). 
and Italian imprints are numerous. The holdings in mathematics cover both classical and contemporary texts. Among the former are books in the strong Euclid collection, including the first printed edition of the Elements (in Latin with the commentary by Campano of Novara), the 1505 folio with the commentary by Bartolomeo Zamberti, and the 1543 edition with the first Italian translation by Niccolò Tartaglia, the Brescian mathematician and expert on the science of artillery whose own works are well represented in the science collection. ${ }^{96}$ The Franciscan friar Luca Pacioli published his own Latin translation of the Elements in 1509. That same year, he issued his famous treatise Divina proportione ${ }^{97}$ an elegant book with a series of fifty-nine woodcut illustrations after drawings by Pacioli's friend, Leonardo da Vinci.

Another beautiful edition of a scientific text is the Ornithologiae by the naturalist Ulisse Aldrovandi. ${ }^{98}$ The zoology collections also include books on the art of the farrier, such as Rusius's Opera de l'arte del malscalcio and Claudio Corte's Il cavallerizzo. ${ }^{99}$ Among the Fisher's significant holdings in agriculture are two copies of the Aldine edition of the Scriptores rei rusticae, an anthology of the agricultural works of Cato, Varro, Palladius, and Columella. ${ }^{100}$ Pietro Marino's translation of Palladius's De re rustica is available in a Sienese edition. ${ }^{101}$

The holdings of Renaissance books in the general science section are crowned by the Stillman Drake Galileo Collection. One of the strongest in the world, this special collection brings together the writings of the Italian physicist and astronomer and his contemporaries, as well as material on related aspects

96. Euclid, Elementa geometrica (Venice: Erhard Ratdolt, 1482); Euclidis Megarēsis (Venice: Giovanni Tacuino, 1505; this book is part of the Hannah Collection); Euclide Megarense philosopho (Venice: Venturino Ruffinelli, 1543).

97. Euclidis Megarensis ... opera a Campano interprete fidissimo tralata (Venice: Paganino Paganini, 1509); Divina proportione (Venice: P. Paganini, 1509).

98. Bologna: Giovanni Battista Bellagamba, 1600. The first edition, but volume 2 only. The folio volume was donated by Buchanan in 1950 (Healey, From Aquinas, 53).

99. Laurentius Rusius, Opera de l'arte del malscalcio (Venice: Girolamo Cavalcalupo, 1559); Claudio Corte, Il cavallerizzo (Venice: Giordano Ziletti, 1573). The former is the Italian translation of the Hippiatria; now in the Hannah Collection, the book was once owned by Thomas Howard, 2nd Earl of Arundel, who left his autograph on the title-page.

100. Libri de re rustica (Venice: Aldo Manuzio \& Andrea Torresano, 1514).

101. Palladio dignissimo et antiquo scriptore della agricultura (Siena: Simone Nardi, 1526). 
of Renaissance science. Its basis was the extensive personal library of Stillman Drake, an American banker who became an expert on Galileo and an important editor of his works. The noted scholar arrived in Toronto in 1967 to join the recently founded Institute for the History and Philosophy of Science and Technology, ${ }^{102}$ and the books and manuscripts he brought with him entered the Fisher over the next four decades through purchase and gift. The large number of Galileo imprints covers all his major publications, including a copy of the first edition of the Dialogue on the Two Chief Systems of the World. ${ }^{103}$ There are also valuable copies of lesser known texts, such as the very rare Dialogo de Cecco di Ronchitti... de la Stella Nuova, traditionally attributed to Girolamo Spinelli but more likely by Galileo himself. ${ }^{104}$ This pamphlet illustrates one of the many controversies generated by Galileo's ideas, which over time involved figures such as Baldassare Capra, Antonio Lorenzini, Lodovico delle Colombe, and Orazio Grassi. The Drake materials allow scholars to study the development of these debates in great detail. ${ }^{105}$

The history of medicine collections in the Fisher incorporate Renaissance books. The Jason A. Hannah Collection in the History of Medical and Related Sciences, donated in 1974, holds a copy of John of Gaddesden's Rosa Anglica, the "first medical work by an Englishman to appear in print," though it did so in the ancient Italian capital of Pavia. ${ }^{106}$ The Hannah Collection also has the first edition of Girolamo Fracastoro's Syphilis sive morbus gallicus, the celebrated physician's account in Latin hexameter of what he called the French Disease. ${ }^{107}$ Among the books of the Toronto Academy of Medicine Collection, which were

102. On Stillman Drake, see Landon, Bibliophilia, 10-11 and 43-45.

103. Dialogo ... sopra i due massimi sistemi del mondo (Florence: Gio. Battista Landini, 1632).

104. Padua: Pietro Paolo Tozzi, 1605. See Stillman Drake, Galileo against the Philosophers in His Dialogue of Cecco di Ronchitti (1605) and Considerations of Alimberto Mauri (1606) (Los Angeles: Zeitlin \& Ver Brugge, 1976).

105. For a selection of this material, see the catalogue of the exhibition held at the Thomas Fisher in 1981: Richard Landon, Galileo and Scientific Controversy (Toronto: Thomas Fisher Rare Book Library, 1981).

106. Landon, Bibliophilia, 53. John of Gaddesden, Rosa anglica practica medicine a capite ad pedes (Pavia: Franciscus Girardengus and Joannes Antonius Biretta, 1492). The folio is in a contemporary blind-tooled calf binding.

107. Hieronymi Fracastorii Syphilis, sive Morbus gallicus (Verona: Stefano Nicolini da Sabbio and Brothers, 1530). 
acquired in 1991, is a copy of the 1522 edition of the Fasciculus medicinae, a compilation of medieval texts on anatomy, uroscopy, phlebotomy, and pestilence: "The Fasciculus is the earliest printed book to include anatomical illustrations of any significance." 108 The Academy Collection also includes a copy of the 1565 Latin edition of Pietro Andrea Mattioli's popular commentary on the De medica materia, Dioscorides's encyclopedia of medical plants. ${ }^{109}$ This book contains a set of detailed folio illustrations made from woodblocks designed by Giorgio Liberale and Wolfgang Meyerpeck and cut in 1562 for a Prague edition of the work. Some of the original blocks have survived, a rare occurrence for sixteenth-century woodblocks, and one was purchased by the Fisher Library in 1990. It shows cichorium hortense, the chicory plant, a herb well known to Italians. $^{110}$

When we move from the texts to the artifacts, from the contents of the books to the volumes as physical objects, we find that the Fisher is an outstanding source for the study of the Italian printed book in the fifteenth and sixteenth centuries. The library's collection of incunables is relatively small, but its two hundred or so editions include items from some of the most important presses in Venice. The Euclid folio cited above is an example of the elegant books issued by the press of the scholar-printer Erhard Ratdolt, who exerted a seminal influence on book design. ${ }^{111}$ There are also books published by Nicolas Jenson and Johann von Köln, two pioneers of the printing industry in the Serenissima. A folio of Plutarch's Lives, for example, is printed in Jenson's influential roman typeface. ${ }^{112}$ As is the case with literature, however, the major strength of

108. Philip Oldfield, Vesalius at 500: An Exhibition Commemorating the Five-Hundredth Anniversary of the Birth of Andreas Vesalius, Exhibition and catalogue by Philip Oldfield (Toronto: University of Toronto Library, 2014), 31. Fasciculus medicie [sic] (Venice : Cesare Arrivabene, 1522).

109. Commentarii in sex libros Pedacii Dioscoridis Anazarbei De medica materia (Venice: Valgrisi, 1565). The Fisher holds copies of several Italian and Latin editions of Mattioli's work, including the 1558 Valgrisi, which contains an earlier set of illustrations.

110. Marie Korey, Richard Landon, and Philip Oldfield, eds., Book History and Print Culture: An Exhibition Celebrating the Collaborative Program at the University of Toronto (Toronto: University of Toronto Library, 2001), 54-55. The woodblock is at duff ff 00025. The illustration produced from it appears on page 502 of the 1565 edition.

111. Euclid, Elementa geometrica (Venice: 1482). On the typographical significance of this edition, see Korey et al., 31-32.

112. Plutarch, Vitae illustrium virorum (Venice: Nicolas Jenson, 1478), part 2 only. Other examples: Biblia latina (Venice: Johannes Herbort for Johann von Köln, Nicolas Jenson and partners, 1481), vols. 
the Fisher's Italian collection in the area of book history lies in the sixteenth century. The library owns books by all of the major and many of the minor printing houses that operated on the peninsula. Blessed with the advantages of rich capital markets and an international commercial network, Venice remained the major centre of the industry throughout the period. The Fisher has about one hundred titles issued by the most prestigious Venetian imprint, the Aldine Press, ranging from the Greek edition of the pseudo-Aristotelian Mechanica printed by Aldus in 1497 to the Orthographiae ratio issued in 1591 by the founder's grandson, Aldus the Younger. ${ }^{113}$ The reputation of the house of Manuzio rested on the prestige of its humanist editions of the Latin and Greek classics. That prestige was matched for books in the vernacular by the Giolito de' Ferrari family firm. Founded by Giovanni in the early years of the century in Trino, the business was led from 1541 to 1578 by his son Gabriele, who turned it into the largest printing and publishing concern of the century. There are over a thousand extant editions that bear the device of the Phoenix, and the Fisher owns copies of about 150, including, as we have seen, important editions of Boccaccio, Ariosto, and the lyric poets. Well represented in the Toronto collections are also the various Venetian firms that competed with Giolito, including Valgrisi, Marcolini, Zoppino, Sessa, Guerra, and the various branches of the Bindoni.

Florence was a minor printing centre in terms of total output, but the character of the material produced by its presses made a significant contribution to the city's continued cultural predominance in the Cinquecento. As ducal printer under Cosimo I de' Medici, Lorenzo Torrentino was responsible for publishing the works of the Accademia Fiorentina and the faculty at the University of Pisa, hence playing a crucial role in the regime's program of promoting Florentine language, literature, and culture. The Fisher holds about

\footnotetext{
1, 2, 4; Johannes Duns Scotus, Quaestiones in quattuor libros Sententiarum Petri Lombardi (Venice: Johannes Herbort for Johann von Köln, Nicolas Jenson and partners, 1481), part 1 of 4. The Fisher's copy of Duns Scotus, Quaestiones in quattuor libros Sententiarum Petri Lombardi (Venice: Johann von Köln \& Johannes Manthen, ca. 1476), contains the commentary on book 4. It is a folio from the Walsh collection and once belonged to Estelle Doheny. Bound by Riviere and Son, it is "the only copy on vellum recorded in the standard sources" (R. Landon, "Introduction," in Korey et al., 7-14: 10; see also 45-47). 113. The twelve leaves of the Mechanica constitute part 4 of the monumental Greek edition of Aristotle's Opera (Venice: Aldus Manutius, 1495-98); Aldo Manuzio, Orthographiae ratio (Venice: Apud Aldus, 1591).
} 
a fifth of the 260 or so of his editions, another sign of the library's value for scholars of literary and cultural history. ${ }^{114}$ Other Florentine publishers present in the collections are the Sermartelli, the local branch of the Giunta publishing empire, Giorgio Marescotti, and Anton Francesco Doni. ${ }^{115}$ For Rome, we have examples of the work of Antonio Blado and his heirs. The library also owns a copy of Euclid's Elements in Arabic translation issued by the Tipografia Orientale Medicea, a press founded by Cardinal Ferdinando de' Medici in 1584 to publish religious and scientific texts in Oriental languages. The celebrated type designer Robert Granjon cut the Arabic types for this large folio. ${ }^{116}$ Among the many small presses in minor cities represented in the collections are Giovanni Mazzocchi and Francesco Rossi da Valenza in Ferrara, and Valente Panizza and Pietro Giacomo Petrucci in Perugia.

Historians of binding will find much that is of interest here. In addition to fifteenth- and sixteenth-century books in contemporary bindings, there are magnificent bindings of later periods, which are evidence of the ways in which Renaissance books were considered by collectors and are thus useful for the history of the discipline. ${ }^{117}$ For example, the copy of Petrarca's 1484 Trionfi e Canzoniere by Petrus de Plasiis mentioned above is in a binding of gold-tooled red morocco bearing the arms of Roberto Ridolfi, one of the great bibliophiles of the last century and an important biographer of Machiavelli and Guicciardini. Marco Guazzo's Errori d'amore and Ariosto's Suppositi are in nineteenth-century French bindings signed by Trautz-Bauzonnet and F. Niedrée, respectively, both in gold-tooled red morocco. ${ }^{118}$

It is evident that the Fisher's holdings in the Renaissance are a rich source for specialists in the history of typography, publishing, the book trade,

114. The Fisher holdings were the basis for Antonio Ricci, "Lorenzo Torrentino and the Cultural Programme of Cosimo I de' Medici," in The Cultural Politics of Duke Cosimo I de' Medici, ed. Konrad Eisenbichler (Aldershot: Ashgate, 2001), 103-19.

115. On Doni's press, see Antonio Ricci, “The Business of Print in Ducal Florence: The Case of Anton Francesco Doni," in Dissonanze Discordi, ed. Giovanna Rizzarelli (Bologna: Il Mulino, 2013), 45-70.

116. Kitāb taḥīr uṣūl li-Uqlīdis (Rome: Typographia Medicea, 1594). See Korey et al., 38-39.

117. The copy of the 1505 folio edition of Euclid cited above "is a particularly fine example of a contemporary alum-tawed pigskin binding" (Korey et al., 33).

118. Marco Guazzo, Comedia intitolata Errori d'amore (Venice: Bindoni and Pasini, 1526); L. Ariosto, Comedia intitolata Li Soppositi (Venice: M. Sessa, 1536). These were first noted by Corrigan, Catalogue of Italian Plays, xiii. 
and collecting, all of whom can also draw from the complementary collections of contemporary printing in other European centres such as Lyon, Paris, and Antwerp. But the value of these extensive resources extends beyond the specialist fields in book history. The range and variety of material, and the fact that a high number of the printers and publishers of the Cinquecento are represented here, makes the Fisher a unique resource for scholars interested in reconstructing the print culture of the period, that is, for the study of cultural history in the widest sense. The collections can support research that begins with printers and publishers but crosses geographic, chronological, and thematic limits to consider larger patterns of knowledge transmission and cultural influence.

What is true of the holdings in book history is true of the Italian Renaissance collections as a whole. In the past fifty years, they have supported not only scholars working strictly within the boundaries of the particular genres and categories surveyed above, but also those pursuing the kind of interdisciplinary research that has always characterized the field of Renaissance studies. The library invites the kind of cultural history that embraces the full range of literary, historical, political, and artistic expressions and forms. For example, the materials have benefitted reconstructions of the culture of Siena and Florence encompassing the political aspects of literary life and the role of academies in those cities. ${ }^{119}$ Throughout the survey above, I indicated illustrative examples of publications based on books in the Fisher. A more comprehensive census of the collection's contribution to Canadian scholarship on the Renaissance is beyond the scope of this article, but it is possible to note that the library has supported the work of faculty and graduate students based in various departments and centres of the University of Toronto, including History, English, French, the CRRS, the Centre for Comparative Literature, and, of course, Italian Studies, where the Italian play collections have traditionally been the basis for critical editions. The Fisher has strengthened the graduate and undergraduate curricula of such programs and helped to make possible the establishment of the Collaborative Program in Book History and Print Culture. Scholars in Toronto and the rest of Canada, and increasingly from abroad, have also carried forward 
projects in the collections. In the past, the library has supported developments such as the move towards greater interdisciplinarity, and it is well positioned to continue to make contributions to innovative scholarship, whatever the direction the field of Renaissance studies might take in the future.

Like their predecessors in the last fifty years, scholars who use the Fisher Library in the future will have the advantage of being able access the full range of resources of the University of Toronto Libraries system. It is the largest academic library in Canada and is ranked among the top three in North America (after Harvard and Yale). Its forty-four libraries hold more than twelve million volumes and about 5.6 million microform collections, and they provide access to over one hundred thousand serial titles, 660,000 electronic journals, and 850,000 electronic books. ${ }^{120}$ Across from the Fisher building is the Robarts Library, one of the great research collections in the humanities and social sciences-its books approaching six million-and very strong in Italian studies and early modern history. Renaissance material is found in the college libraries at Victoria, Trinity, and St. Michael's, the last holding a strong CounterReformation collection. First among the specialized collections useful for interdisciplinary research on Italy is the library of the CRRS. Its holdings of about four thousand rare books printed before 1700 are concentrated mostly in the Erasmus Collection and in its collection of humanist editions of the classics, but there is a not insignificant presence of Italian imprints. The collections of the Pontifical Institute of Mediaeval Studies include fifteenth- and sixteenthcentury books and relevant secondary material. The special collections of the Robertson Davies Library at Massey College focus on the technical aspects of the history of the book. In short, scholars who visit the Fisher can count on a good range of complementary resources, allowing them to pursue the full array of research interests that might fall within the purview of Renaissance studies.

To close this survey, one might hazard a ranking of the Fisher on the basis of its holdings of Italian Renaissance printed books. Setting aside the collections in the great national repositories, including the Biblioteca Nazionale Centrale in Florence, the British Library, and the Bibliothèque nationale de France in Paris, the Fisher ranks, in my view, somewhat below the class of institutions

120. The data are drawn from the UTL web site (http://onesearch.library.utoronto.ca). See "2011-2012 Annual (Library) Statistics, May 1, 2011 to April 30, 2012," http://onesearch.library.utoronto.ca/annualstatistics/2011-2012 (accessed June 15, 2014). A useful summary is found at http://onesearch.library. utoronto.ca/meet-our-chief-librarian-larry-alford (accessed June 15, 2014). 
represented by the Houghton Library at Harvard and the Newberry in Chicago, in the same category as the John Rylands at the University of Manchester, and above the Rare Book \& Manuscript Library at Columbia University. ${ }^{121}$

On the fiftieth anniversary of Renaissance and Reformation /Renaissance et Réforme, of the CRRS, and of the TRRC, it is only fitting that we should also celebrate the library that engaged with these institutions in a mutually beneficial dynamic over these many years. The Fisher Library's varied and rich collections have been a solid foundation for the work of early modern scholars, affording them the materials for individual research as well as for interdisciplinary collaboration. In fostering this community of learning, the Fisher has shaped Renaissance studies in Canada. As Richard Landon wrote in 2005, on the occasion of the fiftieth anniversary of the founding of RBSC:

During this time the University established itself as an internationally recognized research institution, and the library responded to the challenge by providing the resources for the increased scholarly demand. The Department of Rare Books and Special Collections, and then the Fisher Library, has been a vital component of this tremendous growth, and while we can pause and reflect on the achievements of fifty years, the pause will be brief, for the challenges remain and become more diverse and complex with each passing year." ${ }^{22}$

The great challenge today is presented by the digital revolution, which has transformed the resources and possibilities available to scholars in much the same way in which the invention of printing from movable type changed the transmission of knowledge in the fifteenth century. To revive a humanist metaphor, scholarship is a conversation between the living and the dead. Digital technology has given a wondrous new dimension to the conversation. Even in the brave new world of dematerialized texts, though, the voice of the dead carries a unique resonance when it emanates from old books, real books, in the peaceful quiet and gentle light of a reading room as magnificent as the

121. This seems to be in line with Natalie Zemon Davis's overall ranking, as reported in Sandra Martin, "He built": "Social historian Natalie Zemon Davis [...] ranks the Fisher just below international superstar collections, such as the richly endowed Houghton at Harvard and the ancient Bodleian at Oxfordnot bad considering there wasn't even an official rare books room at the U of T until 1957."

122. Landon, Bibliophilia, 18. 
Fisher's, its walls rising high, lined with volumes bearing witness to the ancient dialogue renewed. 